\section{Economic Analysis of Grafting and Anaerobic Soil Disinfestation for Tomato Production in South Carolina}

\author{
Tanner Donahoo, ${ }^{1}$ Lisha Zhang, ${ }^{1}$ Matthew Cutulle, ${ }^{2}$ and \\ Abolfazl Hajihassani ${ }^{3}$
}

ADDITIONAL INDEX WORDs. breakeven price, Meloidogyne incognita, net return, partial budget analysis, root-knot nematode, sensitivity analysis, southern blight, Sclerotium rolfsii, Solanum sisymbriffolium

SuMmARY. Increasing regulations and restrictions regarding on-farm chemical use and growing consumer demands for organic food products warrant the development of efficient biological methods for plant disease control and pest management. Grafting and anaerobic soil disinfestation are two sustainable crop production techniques developed to control and regulate weeds, root-knot nematodes (Meloidogyne incognita), and soilborne pathogens. Therefore, the present study explores the economic impact of using grafting and anaerobic soil disinfestation, independently and in conjunction, to determine the best combination in terms of yield and net returns for producers. This study drew from tomato (Solanum lycopersicum) field trials conducted in 2020 on a 0.5 -acre plot at the Clemson Coastal Research and Education Center in Charleston, SC, where five grafting and three anaerobic soil disinfestation treatments were used in combinations for comparisons. Each treatment combination was subjected to sealed (plastic mulch covering a plot punctured 5 weeks after applying anaerobic soil disinfestation treatment) and unsealed (plastic mulch covering a plot punctured immediately after the application of anaerobic soil disinfestation treatment) plot conditions during the anaerobic soil disinfestation phase of plant bed preparation. Treatment combinations with cottonseed meal carbon-sourced anaerobic soil disinfestation were unviable because of lower net returns compared with treatment combinations without anaerobic soil disinfestation in nearly every case. Grafting ('Roadster' self-grafted) combined with molasses and chicken manure carbon-sourced anaerobic soil disinfestation under unsealed plot conditions was the most optimal treatment combination in the field trials with the greatest gains (net return per acre) to producers. The positive synergistic effects of combining these methods suggest that grafting and anaerobic soil disinfestation yield better results in conjunction than separately.

$\mathrm{P}$ lant grafting is a method whereby tissue from one plant is attached to another to create a more

Received for publication 1 Apr. 2021. Accepted for publication 25 June 2021.

Published online 25 August 2021.

${ }^{1}$ Department of Agricultural Sciences, Clemson University, Clemson, SC 29634

${ }^{2}$ Plant and Environmental Sciences Department, Coastal Research and Education Center, Charleston, SC 29414

${ }^{3}$ Department of Plant Pathology, University of Georgia, Tifton, GA 31794

This project was supported by the U.S. Department of Agriculture Methyl Bromide Transition Program (2019-51102-30202)

T.D. is a Graduate Research Assistant.

L.Z. is Former Assistant Professor, Clemson University.

M.C. and A.H. are Assistants Professors.

L.Z. is the corresponding author. E-mail: lishaz@ clemson.edu.

This is an open access article distributed under the CC BY-NC-ND license (https://creativecommons. org/licenses/by-nc-nd/4.0/).

https://doi.org/10.21273/HORTTECH04858-21 robust and desirable plant. To make a graft, the scion (a cutting from the aerial part, that is, above the stem, of the plant) of one plant is attached to the rootstock (the base of a plant, including the stem and roots) of another plant of the same or related species in such a manner that the scion and rootstock unite and grow together to form an entirely new plant (Garner and Bradley, 2013). This asexual plant propagation method confers increased resistance against biotic and abiotic threats to plant growth in a wide variety of crops while reducing the need for agricultural chemicals and enhancing fruit quality and size (Garner and Bradley, 2013; Singh et al., 2017). Moreover, over the past 30 years, grafting has been widely adopted in European and Asian countries, where intensive production (continuous cropping) is widespread (Barrett et al., 2012; Rysin and Louws, 2015).

Recently, plant grafting has attracted increased attention in the United States (Barrett et al., 2012; Kubota et al., 2008; Louws et al., 2010; Schwarz et al., 2010; Singh et al., 2017), and this interest can be attributed to different factors. Soil fumigation using methyl bromide has been the most widely used traditional method for pathogen and pest control in the United States (Kubota et al., 2008; Osteen, 2003; Piccirillo and Piccirillo, 2010). However, in an effort to reduce ozone depletion, national and global regulations have drastically restricted the availability and use of methyl bromide and similar chemicals (Butler et al., 2014; Osteen, 2003; Rosskopf et al., 2005; U.S. Environmental Protection Agency, 2018, 2020). This shift has created the need for more economical alternatives to chemical soil fumigation (Butler et al., 2014; Louws et al., 2010; Rosskopf et al., 2015), and grafting is one such alternative. In addition, changing market preferences in recent decades have created an increased demand for organic, sustainably farmed products in the United States (Chellemi, 2014). Although grafting can be used to take advantage of this growing market segment by stakeholders for organic food production, grafting on a large scale is still rare in the United States (Djidonou et al., 2013), mainly because of the higher production costs associated with grafted plants, including labor and grafting supplies (for example, plastic tarping, grafting clips, and healing chambers)

\begin{tabular}{llll}
\hline $\begin{array}{l}\text { Units } \\
\begin{array}{l}\text { To convert U.S. to SI, } \\
\text { multiply by }\end{array}\end{array}$ & U.S. unit & SI unit & $\begin{array}{l}\text { To convert SI to U.S., } \\
\text { multiply by }\end{array}$ \\
\hline 0.4047 & $\mathrm{acre}(\mathrm{s})$ & $\mathrm{ha}$ & 2.4711 \\
0.3048 & $\mathrm{ft}$ & $\mathrm{m}$ & 3.2808 \\
3.7854 & $\mathrm{gal}$ & $\mathrm{L}$ & 0.2642 \\
9.3540 & $\mathrm{gal} / \mathrm{acre}$ & $\mathrm{L} \cdot \mathrm{ha}^{-1}$ & 0.1069 \\
0.4536 & $\mathrm{lb}$ & $\mathrm{kg}$ & 2.2046 \\
1.1209 & $\mathrm{lb} / \mathrm{acre}$ & $\mathrm{kg} \cdot \mathrm{ha}^{-1}$ & 0.8922
\end{tabular}

Horflechnology $\cdot$ October $202131(5)$ 
(Louws et al., 2010; Rivard et al., 2010b; Singh et al., 2017).

Anaerobic soil disinfestation (ASD) is another technique that can be used in conjunction with grafting to cater to farmers' growing food production needs to meet the demands of the consumers while adhering to the current legal constraints regarding chemical use in the food industry. Developed independently in the Netherlands and Japan in the 1990s and 2000s, ASD involves the addition of decomposable amendments to the soil, covering the soil with plastic mulch, and irrigating it to saturation during a 2- to 6-week treatment period to create a temporary anaerobic soil environment, which is detrimental to the development of soilborne pests and diseases (Shrestha et al., 2016). ASD relies on biological, rather than chemical, processes to eliminate pests without compromising the quality of crops (Butler et al., 2014; Di Gioia et al., 2016, 2017; Guo et al., 2017, 2018; Lamers et al., 2010) and can be used as an alternative form of organic food production if the carbon source is organic.

As with grafting, producers using ASD as a farming practice can expect an increase in both materials and labor costs compared with those of chemical soil fumigation (Guo et al., 2017; Shi et al., 2019; Shrestha et al., 2016). ASD relies on the application of decomposable carbon additives to the soil to facilitate microbial growth and oxygen consumption; therefore, carbon sources account for the most significant increase in material costs. The economic viability of ASD is largely dependent on the selection, availability, and cost of the carbon additives available near the production sites and at the time of field preparations (Di Gioia et al., 2016). In addition, the labor costs associated with ASD treatments increase notably because of additional labor requirements for the application of carbon sources and impermeable films (Shi et al., 2019; Shrestha et al., 2016; Testen and Miller, 2017). Therefore, both grafting and ASD are environmentally sustainable practices associated with higher production costs (Song et al., 2020; Suansia and Samal, 2021).

Previous economic analyses focused on evaluating each of these practices independently, but not in conjunction, thereby making the additional benefits (and costs) of using grafting and ASD together largely unknown. Therefore, the purpose of the present study was to identify the most profitable practice by combining different types of grafting and ASD treatments and using tomato (Solanum lycopersicum) production in South Carolina as a test case. To the best of our knowledge, this is the first economic analysis to combine both practices for tomato production in South Carolina to provide insight regarding the synergistic effects of using them in combination.

With changing regulations for chemical use and consumer demands tending toward sustainably grown agricultural products, tomato producers in South Carolina need more information about how these production methods interact to meet the legal restrictions and consumer demands in the most economical manner. The findings of this study will allow producers to adopt otherwise costly production practices to increase tomato cultivation in the state.

\section{Materials and methods}

The field trials for this experiment were conducted on a 0.5 -acre plot at the Clemson Coastal Research and Education Center in Charleston, SC. The field was mechanically disked to remove weeds and improve soil granulation and surface uniformity for bedding. A $15 \mathrm{~N}-0 \mathrm{P}-12.5 \mathrm{~K}$ calcium nitrate fertilizer was applied using 50 $\mathrm{lb} /$ acre of nitrogen, and a tractor was used to create six rows of beds. The rows were $300 \mathrm{ft}$ long and split into three main plots of $100 \mathrm{ft}$ each. Each main plot received one of the three carbon source treatments: molasses and chicken manure $(\mathrm{M}+\mathrm{CM})$; cottonseed meal (CSM); or no carbon source (non-ASD). The carbon sources were mixed in the soil using a peanut hoe, and a tractor-mounted plastic bedder and drip tape implement were used to re-bed the field and seal it with clear plastic mulch and drip tape. Clear plastic mulch was used instead of black plastic mulch to help facilitate the solarization of the soil, which makes ASD more effective for pest control. Then, the drip tape was connected to the layflat plastic attached to the centrally controlled field irrigation system, and the beds were sealed and flooded with water from the drip tape to encourage ASD. Immediately after this step, holes were punctured in the plastic mulch on one half of each main plot to alleviate anaerobic conditions.

After 5 weeks, the plastic mulch in the other halves of the anaerobic plots was punctured with holes. The plots punctured immediately after irrigation served as the unsealed treatment condition, whereas the plots punctured 5 weeks later were referred to as the sealed treatment. It was expected that the sealed plots with applied carbon sources would have longer periods of anaerobic soil conditions compared with the carbon source-augmented unsealed plots. Finally, the clear plastic beds were spray-painted black after the 5-week period using a paint-to-water ratio of 1:7. The clear plastic mulch was painted black to reduce the soil temperatures associated with the solarization of the soil and create better conditions for transplanting.

Plots were monitored for entry into an anaerobic state by using probes that measured the redox potential of the soil. The majority of the sealed plots containing a carbon source had redox potentials less than zero, indicating that the plots were anaerobic, whereas the redox potential of carbon source-augmented unsealed plots approached zero; however, these plots did not become completely anaerobic.

For the grafted tomato plants, the 'Roadster' tomato was selected as the plant scion. Tomato cultivars White Star, SIS Syn II, Maxifort, and Roadster (self-grafted) were selected for the plant rootstocks. 'White Star' and 'SIS Syn II' were chosen as plant rootstocks because increased levels of resistance to root-knot nematode (Meloidogyne incognita) have been reported for these two cultivars (Hajihassani et al., 2020). 'Maxifort' was selected as a rootstock because it has been reported to reduce the incidence of southern blight disease caused by Athelia rolfsii (Sclerotium rolfsii) (Rivard et al., 2010a).

Within each of the three main plots, five sub-plots were planted, each with a different scion-to-rootstock combination: 'Roadster' nongrafted (RBN); 'Roadster' scion self-grafted onto 'Roadster' rootstock (RBS); 'Roadster' scion grafted onto 'White Star' rootstock (WST); 'Roadster' scion grafted onto 'Maxifort' rootstock (MAX); and 'Roadster' scion grafted onto 'SIS Syn II' rootstock (SS2). Ten plants of each combination were planted per 
sub-plot and spaced $2 \mathrm{ft}$ apart, making each sub-plot span a total of $20 \mathrm{ft}$. Liquid $7 \mathrm{~N}-0 \mathrm{P}-5.81 \mathrm{~K}$ fertilizer was added to the transplants three times per week. The transplants were irrigated daily through the drip tape connected to the centrally controlled irrigation system. The plots were harvested weekly from 26 June to 27 July 2020.

There were six groups with five treatment combinations per group, resulting in a total of 30 different treatment combinations, and each treatment combination had three replicates $(90$ plots in total). All 30 treatment combinations are summarized in Table 1 . The treatment combinations receiving the same carbon source were divided into two equal groups. Within each sealed group and unsealed group, five treatment combinations were separated based on the grafting treatment used.

DAta. The costs associated with field trials are summarized in Table 2 as the dollar value per acre. Transplants in all the treatment combinations were staked and received the same fertilizers, herbicides, and irrigation. The labor costs were calculated using the average wage rate for field workers in the southeast region from 2018 to 2020 $(\$ 11.61 / \mathrm{h})$ according to data from the Farm Labor Survey (U.S. Department of Agriculture, National Agricultural Statistics Service, 2018, 2019, 2020). The average wage rate over the course of these years was used to account for recent fluctuations in wage rates for field workers in the region.

The costs listed under seeds and seedling production apply to the nongrafted transplants, and those listed under grafted plants apply to the grafted transplants. Although grafted tomato plants used during this study were generated on the site, tomato farmers usually purchase grafted plants from the market. To ensure a graft cost close to the farmer's actual expenditure, we used the market price of grafted tomato transplants in our analyses. During this study in 2020, each of the grafted tomato cultivars (RBS, WST, MAX, and SS2) had the same cost per plant (\$1.50/plant); therefore, they had the same cost per acre $(\$ 10,890 /$ acre $)$ (Guan, 2018).

The prices for carbon inputs used for the ASD treatments were obtained from Feedstuffs $(2018,2019,2020)$ and the Livestock and Poultry Environmental Learning Community (2019). Table 2 also summarizes the total expenditure for each carbon input. Expenditures for carbon inputs, including $1452 \mathrm{gal} /$ acre of molasses, 16,666 $\mathrm{lb} / \mathrm{acre}$ of CSM, and 18,150 lb/acre of chicken manure, were calculated as the product of the average price from 2018 to 2020 and the actual applied rate for each input. Among the three types of carbon inputs used, CSM was the most expensive on a per-acre basis and cost more than molasses and chicken manure combined. Finally, the

Table 1. Anaerobic soil disinfestation (ASD) and grafting treatment combinations used during tomato production field trials.

\begin{tabular}{|c|c|c|c|c|}
\hline Group no. & ASD treatment & Sealed/unsealed ${ }^{\mathrm{z}}$ & Grafting treatments & Treatment no. \\
\hline \multirow[t]{5}{*}{1} & No carbon source & Sealed & 'Roadster' nongrafted & 1 \\
\hline & No carbon source & Sealed & 'Roadster' self-grafted & 2 \\
\hline & No carbon source & Sealed & 'Roadster' grafted to 'White Star' & 3 \\
\hline & No carbon source & Sealed & 'Roadster' grafted to 'Maxifort' & 4 \\
\hline & No carbon source & Sealed & 'Roadster' grafted to 'SIS Syn II' & 5 \\
\hline \multirow[t]{3}{*}{2} & No carbon source & Unsealed & 'Roadster' nongrafted & 6 \\
\hline & No carbon source & Unsealed & 'Roadster' grafted to 'Maxifort' & 9 \\
\hline & No carbon source & Unsealed & 'Roadster' grafted to 'SIS Syn II' & 10 \\
\hline \multirow[t]{4}{*}{3} & Chicken manure + molasses & Sealed & 'Roadster' nongrafted & 11 \\
\hline & Chicken manure + molasses & Sealed & 'Roadster' self-grafted & 12 \\
\hline & Chicken manure + molasses & Sealed & 'Roadster' grafted to 'White Star' & 13 \\
\hline & Chicken manure + molasses & Sealed & 'Roadster' grafted to 'Maxifort' & 14 \\
\hline & Chicken manure + molasses & Unsealed & 'Roadster' grafted to 'White Star' & 18 \\
\hline & Chicken manure + molasses & Unsealed & 'Roadster' grafted to 'Maxifort' & 19 \\
\hline & Chicken manure + molasses & Unsealed & 'Roadster' grafted to 'SIS Syn II' & 20 \\
\hline \multirow[t]{5}{*}{5} & Cottonseed meal & Sealed & 'Roadster' nongrafted & 21 \\
\hline & Cottonseed meal & Sealed & 'Roadster' self-grafted & 22 \\
\hline & Cottonseed meal & Sealed & 'Roadster' grafted to 'White Star' & 23 \\
\hline & Cottonseed meal & Sealed & 'Roadster' grafted to 'Maxifort' & 24 \\
\hline & Cottonseed meal & Sealed & 'Roadster' grafted to 'SIS Syn II' & 25 \\
\hline \multirow[t]{4}{*}{6} & Cottonseed meal & Unsealed & 'Roadster' nongrafted & 26 \\
\hline & Cottonseed meal & Unsealed & 'Roadster' self-grafted & 27 \\
\hline & Cottonseed meal & Unsealed & 'Roadster' grafted to 'White Star' & 28 \\
\hline & Cottonseed meal & Unsealed & 'Roadster' grafted to 'Maxifort' & 29 \\
\hline
\end{tabular}

${ }^{\mathrm{z}}$ Unsealed $=$ plastic mulch covering the plot punctured immediately after the application of the ASD treatment; sealed $=$ plastic mulch covering the plot punctured 5 weeks after the application of the ASD treatment. 
Table 2. Estimated costs of materials used for nongrafted and grafted tomato production associated with anaerobic soil disinfestation (ASD) treatments.

\begin{tabular}{|c|c|}
\hline & Cost $(\$ / \text { acre })^{z}$ \\
\hline \multicolumn{2}{|c|}{ Seeds and seedling production for nongrafted tomato ${ }^{\mathrm{y}}$} \\
\hline 'Roadster' (seeds) & 355.50 \\
\hline Potting soil & 46.00 \\
\hline Flats & 50.00 \\
\hline Seed sowing and care & 108.00 \\
\hline Cost of grafted plants ${ }^{\mathrm{x}}$ & $10,890.00$ \\
\hline \multicolumn{2}{|l|}{ Fertilizer and irrigation costs } \\
\hline Fertilizer $15 \mathrm{~N}-0 \mathrm{P}-12.5 \mathrm{~K}$ granular & 140.00 \\
\hline Fertilizer $7 \mathrm{~N}-0 \mathrm{P}-5.81 \mathrm{~K}$ liquid & 86.00 \\
\hline Irrigation materials, plastic mulch & 379.33 \\
\hline Drip tape & 125.84 \\
\hline \multicolumn{2}{|l|}{ Operating cost } \\
\hline Herbicide & 15.11 \\
\hline Drip tape connector & 140.40 \\
\hline Stakes & 120.00 \\
\hline String & 12.00 \\
\hline \multicolumn{2}{|l|}{ Labor } \\
\hline Bed preparation & 232.20 \\
\hline Planting & 185.76 \\
\hline Harvesting and grading & $1,114.56$ \\
\hline \multicolumn{2}{|l|}{ Anaerobic soil disinfestation costs ${ }^{\mathrm{w}}$} \\
\hline Molasses & $1,266.41$ \\
\hline Cottonseed meal & $2,083.25$ \\
\hline Chicken manure & 574.55 \\
\hline
\end{tabular}

tomato price used for the analysis was the average shipping point price in the region from 2018 to 2020 (U.S. Department of Agriculture, Agricultural Marketing Service, 2020). The average tomato price from 2018 to 2020 was used to account for recent fluctuations in tomato prices.

\section{Results and discussion}

Net Returns. Net returns (dollar value per acre) for all treatment combinations are reported in Table 3 . The treatment combinations were separated based on sealed or unsealed plot conditions during ASD application in portions of the field preparations. A comparison of the grafting and nongrafting treatments indicated that grafting (RBS) under unsealed plots and nongrafting (RBN) under sealed plots yielded the highest net returns of $\$ 10,568.77 /$ acre and $\$ 5583.09 /$ acre, respectively, when both net returns were averaged across all ASD/non-ASD conditions. ASD $(\mathrm{M}+\mathrm{CM})$ yielded the highest net returns under both unsealed and sealed plots compared with the nonASD treatment when averaged across all grafting and nongrafting treatments. Noticeably, 8 of the 10 treatments that used CSM had negative net returns because of lower yields and higher costs of ASD application, thus making it an unviable option for use during ASD field preparations in this region (Table 3 ).

Considering the synergistic effects of grafting (or nongrafting) and ASD (or non-ASD) treatments, grafting (RBS) with ASD $(\mathrm{M}+\mathrm{CM})$ in the unsealed plots was the optimal treatment combination, with a net return of $\$ 27,689.78 /$ acre, and grafting (SS2) with ASD $(\mathrm{M}+\mathrm{CM})$ was the highestperforming treatment combination under sealed plots, with a net return of $\$ 14,411.24 /$ acre. These grafting-ASD treatment combinations markedly outperformed the nongrafted-non-ASD treatment combinations and are likely to yield the highest net returns for producers.

Our field trials revealed that 13 of the 15 unsealed treatment combinations yielded greater average net returns than their sealed counterparts with the same grafted (or nongrafted) tomato cultivar (Table 3), suggesting that the timing of transplantation of the tomato plants needs adjusting. The tomato plants were probably transplanted into the plots earlier than the optimal time, which did not allow the soil in the sealed plots to fully recover from the anaerobic state, thereby stunting the growth of the tomato plants therein. Essentially, the sealed plots containing a carbon source were likely still close to an anaerobic state (i.e., they still had a very low oxygen content) when the tomatoes were transplanted. For instance, when the tomatoes were transplanted, the $\mathrm{pH}$ was still low and organic acid being produced by the anaerobic bacteria was still present in the soil, which is not conducive to growing tomatoes. In contrast, unsealed plots and sealed plots not containing a carbon source typically did not reach a redox potential of less than $100 \mathrm{mV}(<0$ would be anaerobic $)$, making them more hospitable to plant growth than their near-anaerobic counterparts. Therefore, we suspect that increasing the interval for planting after seal punctuation would have to be greater in the anaerobic plots to allow more time for re-oxygenation before the tomatoes were transplanted. This would not be necessary in the plots that did not become anaerobic.

Partial budget analysis. A partial budget analysis is an economic method that compares the added and reduced costs and revenues associated with one treatment compared to another. It is helpful because it considers only the altered portions of the budget of the treatments rather than the entire budget, which allows for a clearer understanding of the overall effect of each treatment. In this study, a partial budget analysis was applied for two groups: one focusing on only ASD treatments and another focusing on only grafting treatments. We compared the costs and benefits of ASDaided tomato production with nonASD production for the first group and those of grafted tomato production with nongrafted production for the second group. These analyses helped determine the effects of ASD and grafting during production on the overall net return.

Because of the overall ineffectiveness of CSM as a viable carbon source 
Table 3. Net returns of nongrafted and grafted tomato production associated with different practices of anaerobic soil disinfestation (ASD) under sealed and unsealed plot conditions and the differences in net returns between sealed and unsealed treatments.

\begin{tabular}{|c|c|c|c|c|}
\hline \multicolumn{5}{|c|}{ Unsealed treatments $(\$ / \text { acre })^{\mathrm{z}}$} \\
\hline Cultivar $^{\mathrm{y}}$ & Non-ASD & CSM & $\mathrm{M}+\mathrm{CM}$ & Avg \\
\hline $\mathrm{RBN}$ & $4,265.46$ & $1,528.81$ & $23,340.56$ & $9,711.61$ \\
\hline RBS & $7,133.64$ & $-3,117.11$ & $27,689.78$ & $10,568.77$ \\
\hline SS2 & $13,478.88$ & $-2,441.93$ & $9,554.30$ & $6,863.75$ \\
\hline WST & $17,922.00$ & $-6,384.11$ & $13,314.98$ & $8,284.29$ \\
\hline \multicolumn{5}{|c|}{ Sealed treatments $(\$ /$ acre $)$} \\
\hline Cultivar & Non-ASD & $\mathrm{CSM}$ & $\mathrm{M}+\mathrm{CM}$ & Avg \\
\hline $\mathrm{RBN}$ & $3,822.60$ & 11.47 & $12,915.20$ & $5,583.09$ \\
\hline MAX & $3,997.32$ & $-10,761.89$ & $3,252.62$ & $-1,170.65$ \\
\hline RBS & -656.34 & $-14,290.25$ & $8,654.06$ & $-2,097.51$ \\
\hline Cultivar & Non-ASD & CSM & $\mathrm{M}+\mathrm{CM}$ & Avg \\
\hline $\mathrm{RBN}$ & 442.86 & $1,517.34$ & $10,425.36$ & $4,128.52$ \\
\hline MAX & $-6,127.44$ & $9,220.20$ & $18,411.36$ & $7,168.04$ \\
\hline RBS & $7,789.98$ & $11,173.14$ & $19,035.72$ & $12,666.28$ \\
\hline SS2 & $12,610.62$ & $6,998.64$ & $-4,856.94$ & $4,917.44$ \\
\hline WST & $9,699.36$ & $2,991.12$ & 355.74 & $4,348.74$ \\
\hline Avg & $4,883.08$ & $6,380.09$ & $8,674.25$ & \\
\hline
\end{tabular}

${ }^{\mathrm{z}}$ Unsealed treatments $=$ plastic mulch covering the plot punctured immediately after the application of the ASD treatment; sealed treatments = plastic mulch covering the plot punctured 5 weeks after the application of the ASD treatment; non-ASD = no carbon treatment $($ no ASD); CSM = cottonseed meal ASD; $\mathrm{M}+\mathrm{CM}=\mathrm{molasses}$ and chicken manure ASD; $\$ 1.00 /$ acre $=\$ 2.4711 /$ ha.

${ }^{\mathrm{y}} \mathrm{RBN}=$ 'Roadster' tomato nongrafted; MAX = 'Roadster' scion grafted onto 'Maxifort' rootstock; RBS = 'Roadster' scion grafted onto 'Roadster' rootstock (selfgrafted); SS2 = 'Roadster' scion grafted onto 'SIS Syn II' rootstock; WST = 'Roadster' scion grafted onto 'White Star' rootstock.

attributable to its large negative impact on net returns (Table 3), the partial budget analysis was conducted using $\mathrm{M}+\mathrm{CM}$ as the carbon source (Table 4). The analysis compared all 10 treatment combinations using $\mathrm{M}+\mathrm{CM}$ to the 10 non-ASD treatments for a constant grafted (or nongrafted) tomato cultivar and plot type (sealed or unsealed). This highlighted the total effects (in terms of the impact on net return) of using ASD $(\mathrm{M}+\mathrm{CM})$ rather than non-ASD production by varying only the ASD/nonASD condition and then comparing the same grafted/nongrafted tomato cultivars under the same plot conditions.

The partial budget analysis mainly indicated the positive impacts of using $\mathrm{M}+\mathrm{CM}$ as the carbon source for tomato production compared to those of non-ASD production when the grafted (or nongrafted) tomato cultivar and plot treatment (sealed or unsealed) are kept constant. The added returns show that $\mathrm{M}+\mathrm{CM}$-aided production resulted in higher tomato yields for 8 of the 10 treatments. Only SS2 and WST unsealed treatments had lower returns; therefore, they should not be combined with ASD $(\mathrm{M}+\mathrm{CM})$ under unsealed conditions. Seven of these eight ASD $(\mathrm{M}+\mathrm{CM})$ treatments showed substantial improvements in the net returns compared with their non-ASD counterparts, with the gains from increased tomato yields outweighing the added costs of $\mathrm{M}+\mathrm{CM}$ aided production for these treatments. In particular, ASD $(\mathrm{M}+\mathrm{CM})$ had the most significant gains when compared to non-ASD treatment when combined with grafting MAX in the unsealed treatments and SS2 in the sealed treatments, with increases of $\$ 23,794$.10/acre and $\$ 13,542.98 /$ acre, respectively, in the net returns. These results indicate that $\mathrm{M}+\mathrm{CM}$-aided production is better for net returns than non-ASD production when paired with the right grafted tomato cultivars.

Table 5 lists the results of the partial budget analysis conducted using grafted tomato production compared to nongrafted tomato production. Treatment combinations with ASD
(CSM) were excluded because of their ineffectiveness in terms of yield and net returns (Table 3 ). The reduced costs were all the same and reflected the reduced costs associated with forgoing seedling production (using grafted transplants instead). Fifteen of the 16 grafted treatments had higher tomato yields than their nongrafted counterparts (keeping ASD and plot treatments constant). However, only 8 of the 15 treatments with higher yields resulted in higher net returns to the producer because of the high cost of grafted transplants. The higher costs of grafted tomato cultivars outweighed the revenue gains from their increased yields for approximately half of the treatment combinations. For both the sealed and unsealed treatments, grafting (WST) without ASD had the most dramatic increase in tomato yield and overall net return $(\$ 13,656.54 /$ acre under unsealed conditions and $\$ 4,400.04 /$ acre under sealed conditions), indicating that this scion-torootstock combination is the best (of 
Table 4. Added and reduced costs, added and reduced returns, and total negative and positive effects incurred from anaerobic soil disinfestation (ASD)-aided tomato production using molasses and chicken manure relative to production without ASD under the same grafted (or nongrafted) and plot (sealed or unsealed) conditions.

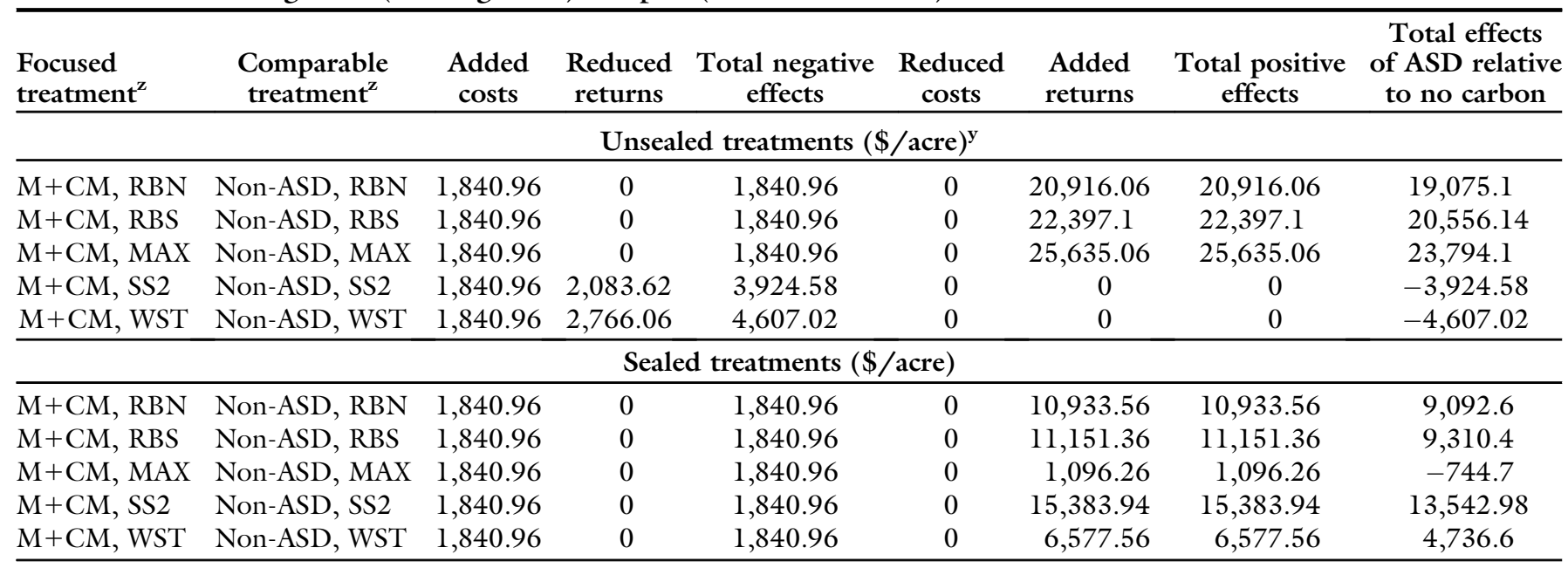

${ }^{\mathrm{z}} \mathrm{RBN}$ = 'Roadster' tomato nongrafted; MAX = 'Roadster' scion grafted onto 'Maxifort' rootstock; RBS = 'Roadster' scion grafted onto 'Roadster' rootstock (selfgrafted); SS2 = 'Roadster' scion grafted onto 'SIS Syn II' rootstock; WST = 'Roadster' scion grafted onto 'White Star' rootstock.

${ }^{y}$ Unsealed treatments = plastic mulch covering the plot punctured immediately after the application of the ASD treatment; sealed treatments = plastic mulch covering the plot punctured 5 weeks after the application of the ASD treatment; $\$ 1.00 /$ acre $=\$ 2.4711 / \mathrm{ha}$.

the grafted cultivars considered during this study) for producers interested in grafting only (that is, not interested in ASD).

BREAKEVEN PRICES ANALYSIS OF MAJOR FACTORS OF PRODUCTION. The analysis of net returns and partial budgets was conducted based on one set of prices for tomatoes and inputs. Therefore, by calculating the breakeven prices for major inputs used for grafting and ASD (M+CM), we compared the treatments to determine the best practice with varying tomato prices and major costs of ASD and grafting.
The breakeven price for a factor of production is the price at which the production method using an input generates the same net return as the alternative method that does not use it. In practice, the breakeven price of an input represents the maximum a producer would be willing to pay to

Table 5. Added and reduced costs, added and reduced returns, and total negative and positive effects incurred from grafted tomato production relative to nongrafted production under the same anaerobic soil disinfestation (ASD) and plot (sealed or unsealed) conditions.

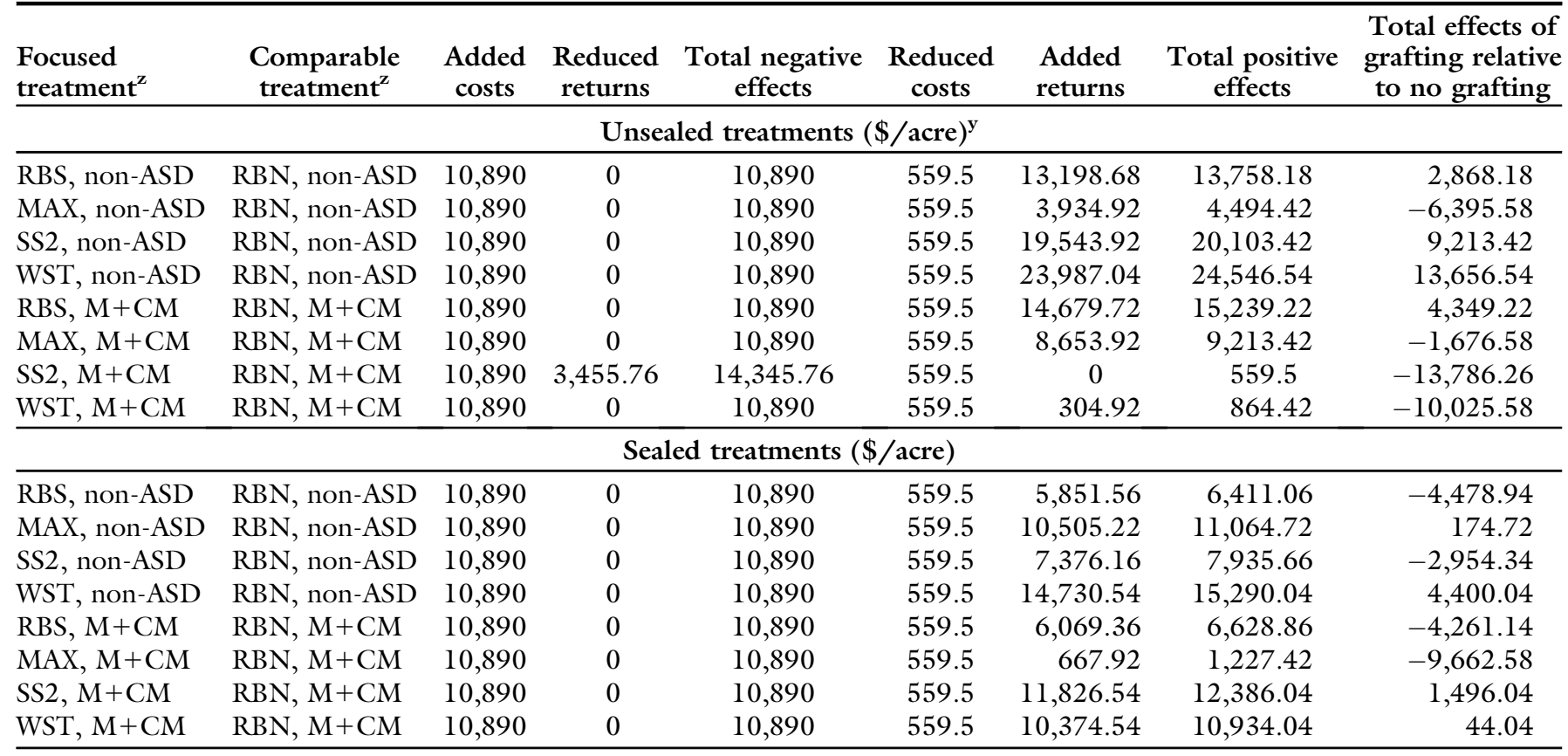

$\overline{{ }^{2} \mathrm{RBN}}=$ 'Roadster' tomato nongrafted; MAX = 'Roadster' scion grafted onto 'Maxifort' rootstock; RBS = 'Roadster' scion grafted onto 'Roadster' rootstock (selfgrafted); SS2 = 'Roadster' scion grafted onto 'SIS Syn II' rootstock; WST = 'Roadster' scion grafted onto 'White Star' rootstock; non-ASD = no carbon treatment (no ASD); $\mathrm{M}+\mathrm{CM}=$ molasses and chicken manure ASD.

${ }^{\mathrm{y}}$ Unsealed treatments = plastic mulch covering the plot punctured immediately after the application of the ASD treatment; sealed treatments = plastic mulch covering the plot punctured 5 weeks after the application of the ASD treatment; $\$ 1.00 /$ acre $=\$ 2.4711 / \mathrm{ha}$. 
Table 6. Breakeven prices for molasses as the major input for anaerobic soil disinfestation (ASD)-aided tomato production relative to non-ASD tomato production under the same grafted (or nongrafted) and plot (sealed or unsealed) conditions.

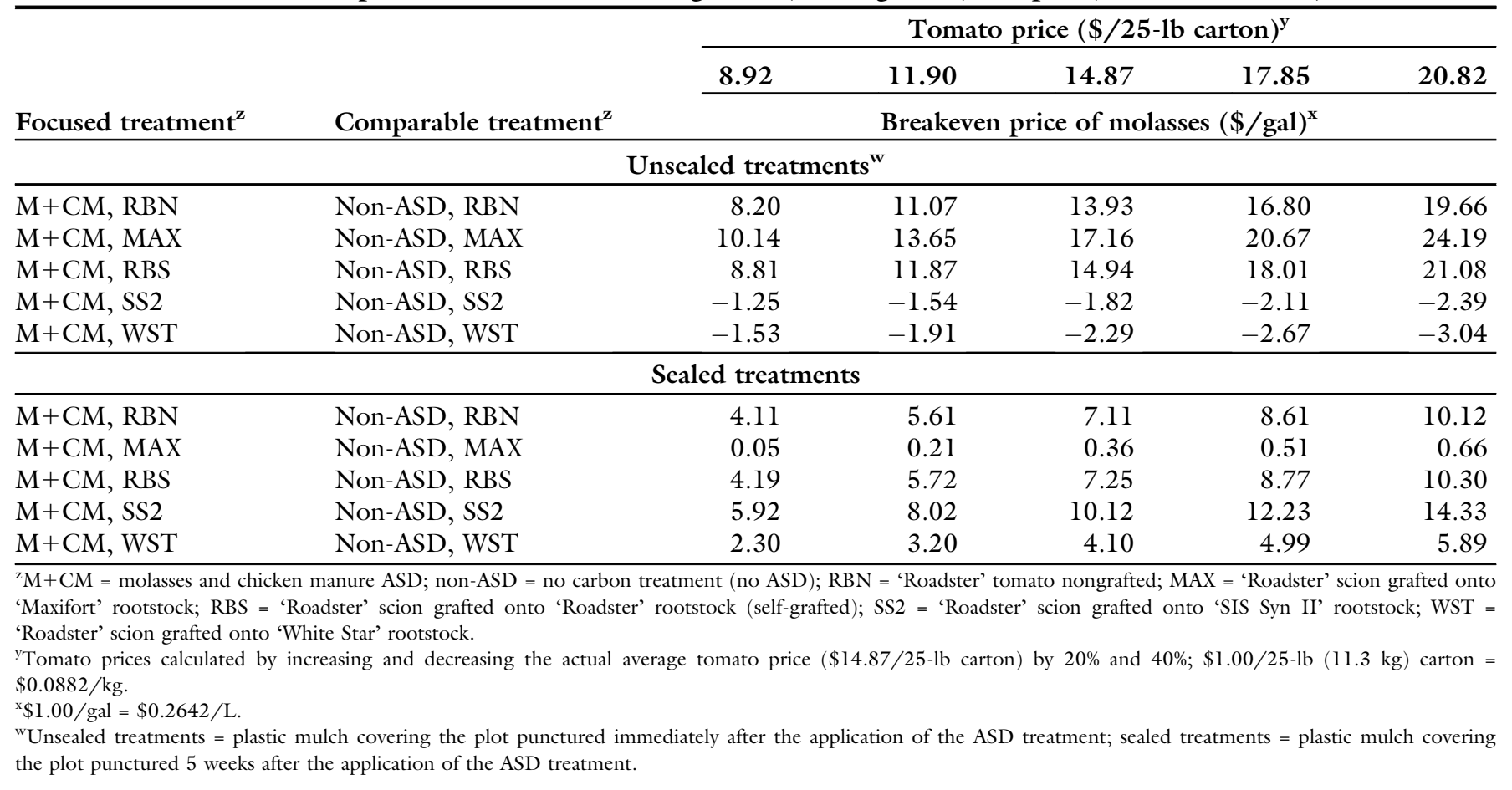

adopt a production method that uses this input. In this study, breakeven prices were calculated for three major factors of production: molasses (the first component of $\mathrm{M}+\mathrm{CM}$-aided ASD); chicken manure (the second component of $\mathrm{M}+\mathrm{CM}$-aided ASD); and grafted transplants.

Table 6 shows the breakeven prices for molasses at different tomato prices. The tomato prices were generated by varying average tomato prices from 2018 to 2020 ( $\$ 14.87$ per $25-\mathrm{lb}$ carton) as follows: $40 \%$ decrease; $20 \%$ decrease; no change; $20 \%$ increase; and $40 \%$ increase. Then, the 10 ASD $(\mathrm{M}+\mathrm{CM})$ treatments were compared with the 10 non-ASD treatment combinations.

Breakeven prices of molasses determined whether ASD $(\mathrm{M}+\mathrm{CM})$ is more profitable than non-ASD at different levels of tomato prices. For example, when the plot is unsealed and the grafting (MAX) is used, the breakeven price of molasses used for ASD $(\mathrm{M}+\mathrm{CM})$ is $\$ 17.16 / \mathrm{gal}$ at a tomato price of $\$ 14.87 /$ carton. If the actual market price of molasses is higher than $\$ 17.16 / \mathrm{gal}$, then it would be more costly to apply molasses as a component carbon source for ASD than to use non-ASD. In this case, the producer would benefit from choosing the nonASD treatment rather than ASD
$(\mathrm{M}+\mathrm{CM})$. However, if tomato prices were $20 \%$ higher (\$17.85/carton), then it would still be profitable to pay $\$ 17.16 / \mathrm{gal}$ of molasses to use ASD $(\mathrm{M}+\mathrm{CM})$ because the increased tomato price increases the breakeven price for molasses to $\$ 20.67 / \mathrm{gal}$.

In general, higher favorable breakeven prices indicate that the ASD $(\mathrm{M}+\mathrm{CM})$ treatment has greater net returns than the non-ASD treatments; therefore, the producers can pay more for molasses and expect higher returns from using the ASD treatment with constant grafted/nongrafted cultivar and plot conditions. Among the unsealed plots, ASD $(\mathrm{M}+\mathrm{CM})$ combined with grafting (MAX) had the highest breakeven prices for molasses, ranging from $\$ 10.14$ to $\$ 24.19$ per gallon, whereas ASD $(\mathrm{M}+\mathrm{CM})$ combined with grafting (SS2) had the highest breakeven prices among the sealed plots, ranging from $\$ 5.92$ to $\$ 14.33$ per gallon.

The negative breakeven prices in Table 6 suggest that ASD $(\mathrm{M}+\mathrm{CM})$ is less profitable than non-ASD when combined with grafting SS2 or WST under unsealed plot conditions. In the case of negative breakeven prices, the prices listed represent the minimum amount that the tomato producers must receive per gallon of molasses rather than spend to benefit from using ASD $(\mathrm{M}+\mathrm{CM})$ in their production practice. The more negative the breakeven price, the greater the subsidy a producer must receive to use ASD $(\mathrm{M}+\mathrm{CM})$ during production.

The breakeven prices for CM are summarized in Table 7 . The results are similar to those of molasses. When the plot is unsealed, breakeven prices of $\mathrm{CM}$ are the highest for ASD $(\mathrm{M}+\mathrm{CM})$ combined with grafting (MAX), ranging from $\$ 0.77 / \mathrm{lb}$ to $\$ 1.90 / \mathrm{lb}$, whereas the breakeven prices in sealed plots are the highest when ASD $(\mathrm{M}+\mathrm{CM})$ is combined with grafting (SS2), ranging from $\$ 0.44 / \mathrm{lb}$ to $\$ 1.11 / \mathrm{lb}$. These ASD (M+CM) treatment combinations have larger net returns than the non-ASD treatment combinations.

With the unsealed condition, breakeven prices of CM are negative when ASD $(\mathrm{M}+\mathrm{CM})$ is combined with grafting SS2 (range, $-\$ 0.14 / \mathrm{lb}$ to $-\$ 0.23 / \mathrm{lb}$ ) or WST (range, $-\$ 0.16$ / $\mathrm{lb}$ to $-\$ 0.28 / \mathrm{lb})$. Noticeably, when the tomato price is lower than $\$ 17.85$ / carton, the breakeven prices of CM are negative in the sealed plots combined with grafting MAX; however, when the tomato price is higher than $\$ 17.85 /$ carton, the breakeven prices of CM are positive under the same conditions. This suggests that this grafted tomato cultivar and plot treatment combination 
Table 7. Breakeven prices for chicken manure as the major input for anaerobic soil disinfestation (ASD)-aided tomato production relative to non-ASD tomato production under the same grafted (or nongrafted) and plot (sealed or unsealed) conditions.

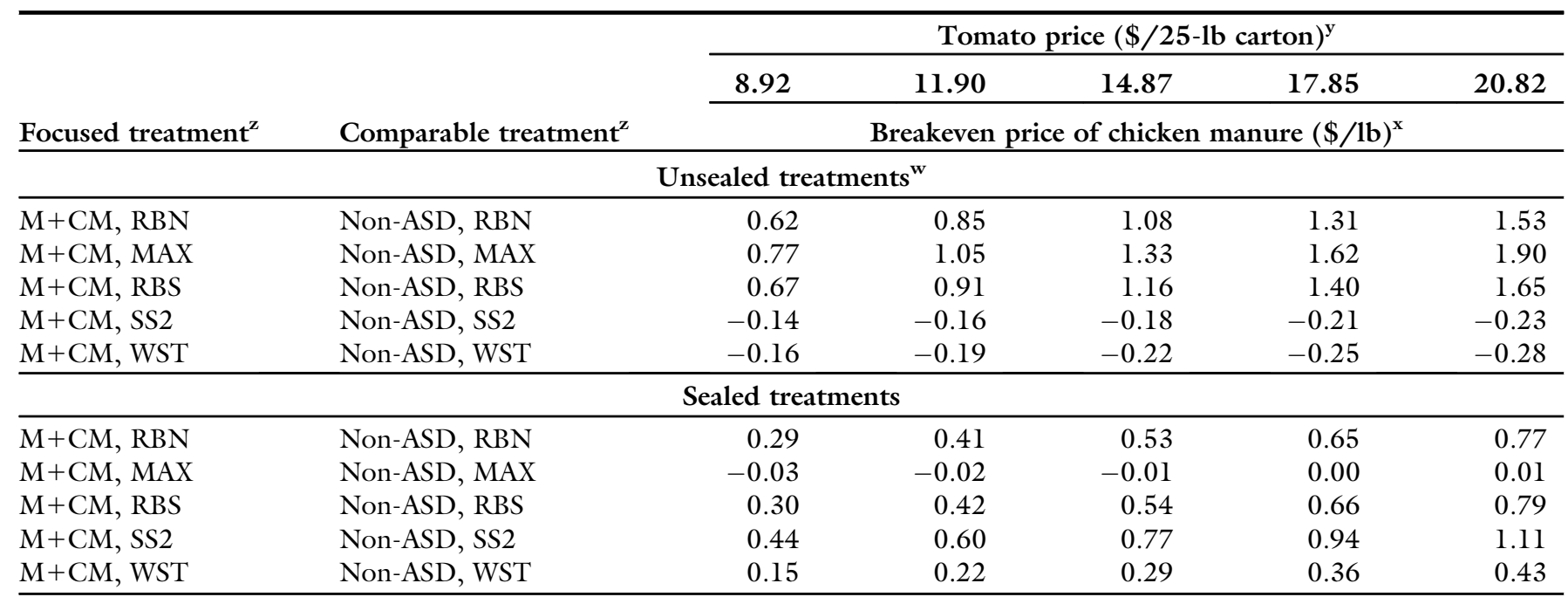

${ }^{\mathrm{z}} \mathrm{M}+\mathrm{CM}=$ molasses and chicken manure ASD; non-ASD = no carbon treatment (no ASD); RBN = 'Roadster' tomato nongrafted, MAX = 'Roadster' scion grafted onto 'Maxifort' rootstock; RBS = 'Roadster' scion grafted onto 'Roadster' rootstock (self-grafted); SS2 = 'Roadster' scion grafted onto 'SIS Syn II' rootstock; WST = 'Roadster' scion grafted onto 'White Star' rootstock.

${ }^{\mathrm{y}}$ Tomato prices calculated by increasing and decreasing the actual average tomato price $(\$ 14.87 / 25-\mathrm{lb}$ carton $)$ by $20 \%$ and $40 \% ; \$ 1.00 / 25-\mathrm{lb}(11.3 \mathrm{~kg})$ carton $=\$ 0.0882 / \mathrm{kg}$. ${ }^{\mathrm{x}} \$ 1.00 / \mathrm{lb}=\$ 0.4536 / \mathrm{kg}$.

${ }^{\mathrm{w}}$ Unsealed treatments = plastic mulch covering the plot punctured immediately after the application of ASD treatment; sealed treatments = plastic mulch covering the plot punctured 5 weeks after the application of the ASD treatment.

generates positive net returns compared with non-ASD only with high tomato prices.
Table 8 shows the breakeven prices for grafted plants as the production factor of interest. The treatment combinations using grafted tomato cultivars were compared with the treatment combinations that used the

Table 8. Breakeven prices for grafted tomato plants relative to nongrafted tomato plants under the same anaerobic soil disinfestation (ASD) and plot (sealed or unsealed) conditions.

\begin{tabular}{|c|c|c|c|c|c|c|}
\hline \multirow[b]{2}{*}{ Focused treatment $^{\mathrm{z}}$} & \multirow[b]{2}{*}{ Comparable treatment $\mathrm{z}^{\mathrm{z}}$} & \multicolumn{5}{|c|}{ Tomato price $(\$ / 25-1 b \text { carton })^{\mathrm{y}}$} \\
\hline & & \multicolumn{5}{|c|}{ Breakeven price of grafted plant (\$/plant) } \\
\hline MAX, non-ASD & RBN, non-ASD & 0.40 & 0.51 & 0.62 & 0.73 & 0.83 \\
\hline RBS, non-ASD & RBN, non-ASD & 1.16 & 1.52 & 1.89 & 2.25 & 2.61 \\
\hline MAX, M+CM & $\mathrm{RBN}, \mathrm{M}+\mathrm{CM}$ & 0.79 & 1.03 & 1.26 & 1.50 & 1.74 \\
\hline $\mathrm{RBS}, \mathrm{M}+\mathrm{CM}$ & $\mathrm{RBN}, \mathrm{M}+\mathrm{CM}$ & 1.28 & 1.69 & 2.09 & 2.49 & 2.89 \\
\hline $\mathrm{SS} 2, \mathrm{M}+\mathrm{CM}$ & $\mathrm{RBN}, \mathrm{M}+\mathrm{CM}$ & -0.21 & -0.30 & -0.40 & -0.49 & -0.59 \\
\hline WST, $\mathrm{M}+\mathrm{CM}$ & $\mathrm{RBN}, \mathrm{M}+\mathrm{CM}$ & 0.10 & 0.11 & 0.12 & 0.13 & 0.14 \\
\hline \multicolumn{7}{|c|}{ Sealed treatments } \\
\hline $\mathrm{MAX}, \mathrm{M}+\mathrm{CM}$ & $\mathrm{RBN}, \mathrm{M}+\mathrm{CM}$ & 0.13 & 0.15 & 0.16 & 0.18 & 0.20 \\
\hline $\mathrm{RBS}, \mathrm{M}+\mathrm{CM}$ & $\mathrm{RBN}, \mathrm{M}+\mathrm{CM}$ & 0.57 & 0.74 & 0.90 & 1.07 & 1.23 \\
\hline $\mathrm{SS} 2, \mathrm{M}+\mathrm{CM}$ & $\mathrm{RBN}, \mathrm{M}+\mathrm{CM}$ & 1.05 & 1.37 & 1.69 & 2.01 & 2.34 \\
\hline WST, $\mathrm{M}+\mathrm{CM}$ & $\mathrm{RBN}, \mathrm{M}+\mathrm{CM}$ & 0.93 & 1.21 & 1.49 & 1.78 & 2.06 \\
\hline
\end{tabular}


nongrafted tomato plants (RBN) for a breakeven price analysis. The analysis suggested that the grafting treatment would be a better option if the actual market price of grafted plants is less than the breakeven price. Grafting (WST) combined with non-ASD had the highest breakeven prices under both unsealed (\$2.05/plant to $\$ 4.68$ / plant) and sealed (\$1.29/plant to $\$ 2.90 /$ plant) conditions. These grafted treatment combinations provide the most significant gains to producers when compared to the nongrafted alternatives. In contrast, grafting (SS2) combined with ASD $(\mathrm{M}+\mathrm{CM})$ under unsealed plot conditions was the only treatment combination to have negative breakeven prices $(-\$ 0.21 /$ plant to $-\$ 0.59 /$ plant), indicating that producers would not benefit more from grafting (SS2) instead of the nongrafted alternatives unless an amount equal to the breakeven price per plant was subsidized.

\section{Conclusions}

With stricter regulations regarding agriculture chemical use and increasing consumer demands for organic food products, farmers will need more effective and sustainable methods for managing soilborne diseases and pests. The economic analysis used for this study focused on determining the best combination of grafting and ASD treatments under both sealed and unsealed plot conditions.

Based on the current set of input costs and tomato prices, the best treatment under unsealed plot conditions is grafting (RBS) with ASD $(\mathrm{M}+\mathrm{CM})$, whereas the best treatment under sealed conditions is grafting (SS2) with ASD $(\mathrm{M}+\mathrm{CM})$. These grafting-ASD combinations generate the most considerable net returns for producers. Production using ASD $(\mathrm{M}+\mathrm{CM})$ was found to perform markedly better than non-ASD production under both sealed and unsealed plot conditions when ASD $(\mathrm{M}+\mathrm{CM})$ was combined with nongrafted (RBN) or grafted (RBS). For producers not interested in using ASD, grafting (WST) combined with nonASD still outperformed nongrafted treatments under both sealed and unsealed plot conditions. However, the synergistic effects of using the optimal grafting and ASD treatment combinations allow for much greater yields and net returns than those occurring when using only one of the methods.

When input costs and tomato prices are different from current values, we also compare the different practices by calculating breakeven prices. Grafting (MAX) combined with ASD $(\mathrm{M}+\mathrm{CM})$ under unsealed conditions and grafting (SS2) combined with ASD $(\mathrm{M}+\mathrm{CM})$ under sealed conditions were the treatment combinations with the highest breakeven prices for both molasses and chicken manure. Grafting (WST) with non-ASD under unsealed conditions and grafting (SS2) combined with ASD $(\mathrm{M}+\mathrm{CM})$ under sealed conditions were the treatment combinations with the highest breakeven prices for grafted transplants. These treatment combinations were the most resistant to increases in input prices (molasses, chicken manure, and grafted transplants) and maintained greater net returns than the nongrafted-non-ASD treatment combinations (under constant plot conditions) as long as the actual input prices were less than the breakeven prices. The results of our simulations also indicate another major implication of this research: given varying inputs costs and tomato prices, growers can decide which production practices would be the most profitable for them based not only on the current price set but also on potential future prices, as simulated in this study.

As technology and research continue to optimize ASD and grafting applications by lowering the costs and increasing the yields associated with these production methods, the profitability of ASD and grafting in food production will increase. Growing consumer demands for organic food products may also allow for increased price premiums for organic food, thus aiding profit gains from ASD and grafting in the future. Positive impacts on the environment and the increased long-term sustainability of soils from using organic methods for soilborne disease management may make control methods like ASD and grafting even more attractive in the long term.

This study was based on the production of an average producer, and the results and data collected were from small-scale field trials. For larger, more commercial tomato production operations, increased economic gains from ASD and grafting may be realized because of the benefits of economics of scale. That is, as production size increases, the per-unit costs of ASD and grafting in terms of material and labor costs are likely to decrease. The most likely major drawback of combining ASD and grafting for tomato production is the potential cost associated with training growers to use both practices because, at present, most growers are probably only familiar with one practice or the other, but not both. The necessary training may generate associated costs. However, without knowledge of the training costs associated with different groups of growers, we could not include such considerations in our present analysis.

\section{Literature cited}

Barrett, C.E., X. Zhao, and A.W. Hodges. 2012. Cost benefit analysis of using grafted transplants for root-knot nematode management in organic heirloom tomato production. HortTechnology 22:252-257.

Butler, D.M., N. Kokalis-Burelle, J.P. Albano, T.G. McCollum, J. Muramoto, C. Shennan, and E.N. Rosskopf. 2014. Anaerobic soil disinfestation (ASD) combined with soil solarization as a methyl bromide alternative: Vegetable crop performance and soil nutrient dynamics. Plant Soil 378:365-381.

Chellemi, D.O. 2014. Plant health management: Soil fumigation, p. 456-459. In: N.K. Van Alfen (ed.). Encyclopedia of agriculture and food systems. Academic Press, Cambridge, MA.

Di Gioia, F., M. Ozores-Hampton, J. Hong, N. Kokalis-Burelle, J. Albano, X. Zhao, Z. Black, Z. Gao, C. Wilson, J. Thomas, K. Moore, M. Swisher, H. Guo, and E.N. Rosskopf. 2016. The effects of anaerobic soil disinfestation on weed and nematode control, fruit yield, and quality of Florida fresh-market tomato. HortScience 240:194-205.

Di Gioia, F., M. Ozores-Hampto, X. Zhao, J. Thomas, P. Wilson, Z. Li, and E.N. Rosskopf. 2017. Anaerobic soil disinfestation impact on soil nutrients dynamics and nitrous oxide emissions in fresh-market tomato. Agric. Ecosyst. Environ. 240:194-205.

Djidonou, D., Z. Gao, and X. Zhao. 2013. Economic analysis of grafted tomato production in sandy soils in northern Florida. HortTechnology 23:613-621.

Feedstuffs. 2018. Grain \& ingredient cash market comparisons, 5/2/18. 29 Sept. 2020. <https://www.feedstuffs.com/ ingredient-prices/grain-ingredient-cashmarket-comparisons-5218>.

Feedstuffs. 2019. Grain \& ingredient cash market comparisons, 11/13/19. 29 Sept. 
2020. < https://www.feedstuffs.com/ ingredient-prices/grain-ingredient-cashmarket-comparisons-111319>.

Feedstuffs. 2020. Grain \& ingredient cash market comparisons, 5/6/2020. 29 Sept. 2020. <https://www.feedstuffs.com/ ingredient-prices/grain-ingredient-cashmarket-comparisons-562020>.

Garner, R.J. and S. Bradley. 2013. The grafter's handbook. Chelsea Green Publ., White River Junction, VT.

Guan, W. 2018. Is it economically sound to grow grafted tomatoes? Purdue Univ. Coop. Ext. Serv., West Lafayette, IN.

Guo, H., F. Di Gioia, X. Zhao, M. Ozores-Hampton, M.E. Swisher, J. Hong, and E.N. Rosskopf. 2017. Optimizing anaerobic soil disinfestation for fresh market tomato production: Nematode and weed control, yield, and fruit quality. Scientia Hort. 218:105-116.

Guo, H., X. Zhao, E.N. Rosskopf, F. Di Gioia, J.C. Hong, and D.H. Mcnear. 2018. Impacts of anaerobic soil disinfestation and chemical fumigation on soil microbial communities in field tomato production system. Appl. Soil Ecol. 126:165-173.

Hajihassani, A., W.B. Rutter, T. Shartz, M. Woldemeskel, M.E. Ali, and N. Hamidi. 2020. Characterization of resistance to major tropical root-knot nematodes in Solanum sisymbriifolium. Phytopathology 110:666-673.

Kubota, C., M.A. McClure, N. KokalisBurelle, M.G. Bausher, and E.N. Rosskopf. 2008. Vegetable grafting: History, use, and current technology status in North America. HortScience 43:1664-1668.

Lamers, J., W. Runia, L. Molendijk, and P. Bleeker. 2010. Perspectives of anaerobic soil disinfestation. Acta Hort. (883):277-283.

Louws, F.J., C.L. Rivard, and C. Kubota. 2010. Grafting fruiting vegetables to manage soilborne pathogens, foliar pathogens, arthropods and weeds. Scientia Hort. 127:127-146.

Osteen, C.D. 2003. Methyl bromide phaseout proceeds: Users request exemptions. 15 Sept. 2020. <https://www.ers. usda.gov/amber-waves/2003/april/ methyl-bromide-phaseout-proceeds $/>$.

Livestock and Poultry Environmental Learning Community. 2019. Impact of fluctuating fertilizer prices on poultry manure nutrient value. 29 Sept. 2020. $<$ https://lpelc.org/impact-of-fluctuatingfertilizer-prices-on-poultry-manure-nutrientvalue $/>$.

Piccirillo, V.J. and A.L. Piccirillo. 2010. Methyl bromide, p. 2267-2279. In: R. Krieger (ed.). Hayes' handbook of pesticide toxicology. 3rd ed. Academic Press, Cambridge, MA.

Rivard, C.L., S. O'Connell, M.M. Peet, and F.J. Louws. 2010a. Grafting tomato with interspecific rootstock to manage diseases caused by Sclerotium rolfsii and southern root-knot nematode. Plant Dis. 94:1015-1021.

Rivard, C.L., O. Sydorovych, S. O'Connell, M.M. Peet, and F.J. Louws. 2010b. An economic analysis of two grafted tomato transplant production systems in the United States. HortTechnology 20: 794-803.

Rosskopf, E.N., D.O. Chellemi, N. KokalisBurelle, and G.T. Church. 2005. Alternatives to methyl bromide: A Florida perspective. Plant Health Prog. 6:19.

Rosskopf, E.N., P. Serrano-Pérez, J. Hong, U. Shrestha, M. del Carmen Rodríguez-Molina, K. Martin, N. KokalisBurelle, C. Shennan, J. Muramoto, and D. Butler. 2015. Anaerobic soil disinfestation and soilborne pest management, p. 277-305. In: M. Meghvansi and A. Varma (eds.). Organic amendments and soil suppressiveness in plant disease management. Springer, New York, NY.

Rysin, O. and F.J. Louws. 2015. Decision tool for growers to evaluate economic impact of grafting technology adoption: An application to open-field conventional tomato production. HortTechnology 25: 132-138.

Schwarz, D., Y. Rouphael, G. Colla, and J.H. Venema. 2010. Grafting as a tool to improve tolerance of vegetables to abiotic stresses: Thermal stress, water stress and organic pollutants. Scientia Hort. 127: 162-171.

Shi, L., J. Wang, Z. Gao, X. Zhao, F. Di Gioia, H. Guo, J. Hong, M. OzoresHampton, and E. Rosskopf. 2019. Economic analysis of anaerobic soil disinfestation for open-field fresh-market tomato production in southwest and north Florida. HortTechnology 29:777-787.

Shrestha, U., R.M. Augé, and D.M. Butler. 2016. A meta-analysis of the impact of anaerobic soil disinfestation on pest suppression and yield of horticultural crops. Front. Plant Sci. 7:1254.

Singh, H., P. Kumar, S. Chaudhari, and M. Edelstein. 2017. Tomato grafting: A global perspective. HortScience 52:1328-1336.

Song, Z., S. Massart, D. Yan, H. Cheng, M. Eck, C. Berhal, C. Ouyang, Y. Li, Q. Wang, and A. Cao. 2020. Composted chicken manure for anaerobic soil disinfestation increased the strawberry yield and shifted the soil microbial communities. Sustainability 12:6313.

Suansia, A. and K.C. Samal. 2021. Vegetable grafting: A sustainable and eco- $^{-}$ friendly strategy for soilborne pest and disease management. J. Pharmacogn. Phytochem. 10:1634-1642.

Testen, A. and S. Miller. 2017. Getting to the root of the matter: Soilborne diseases of tomato. 17 Sept. 2020. <https://u.osu. edu/vegnetnews/2017/09/09/gettingto-the-root-of-the-matter-soilbornediseases-of-tomato/ $>$.

U.S. Department of Agriculture, Agricultural Marketing Service. 2020. Tomato commodity report. U.S. Dept. Agr., Agric. Market. Serv., Washington, DC.

U.S. Department of Agriculture, National Agricultural Statistics Service. 2018. Farm labor report. U.S. Dept. Agr., Natl. Agric. Stat. Serv., Washington, DC.

U.S. Department of Agriculture, National Agricultural Statistics Service. 2019. Farm labor report. U.S. Dept. Agr., Natl. Agric. Stat. Serv., Washington, DC.

U.S. Department of Agriculture, National Agricultural Statistics Service. 2020. Farm labor report. U.S. Dept. Agr., Natl. Agric. Stat. Serv., Washington, DC.

U.S. Environmental Protection Agency. 2018. Methyl bromide. 25 Sept. 2020. <https://www.epa.gov/ods-phaseout/ methyl-bromide $>$.

U.S. Environmental Protection Agency. 2020. Phaseout of class I ozone-depleting substances. 25 Sept. 2020. <https:// www.epa.gov/ods-phaseout/phaseoutclass-i-ozone-depleting-substances $>$. 